\title{
Feminist Histories: conflict, coalitions and the maternal order
}

\author{
Gillian Howie \\ I \\ Introduction
}

For the last twenty years, feminist theory has been presented as a series of ascending waves or generations. The staged story of recent struggles and generations was articulated most clearly by Kristeva in Women's Time. ${ }^{1}$ Since Kristeva's essay, a new generation of women has grown up, and a new terminology with which to reflect on feminism has emerged. Rebecca Walker is often attributed with coining the term 'third wave' in an article 'Becoming the Third Wave' (1992). ${ }^{2}$ Along with Barabara Findlen, Leslie Heywood and Jennifer Drake, Jennifer Baumgardner and Amy Richards and Rory Dicker and Alison Piepmeier, ${ }^{3}$ Rebecca Walker asserts that there is something distinctive about this most recent wave.

Some mark this distinction in terms of chronological generation. The Third Wave Foundation, associated with Rebecca Walker, specified its target membership as women between the ages of 15 and 30. Jennifer Baumgardner and Amy Richards describe the 'third wave' as 'women reared in the wake of the women's liberation movement of the seventies'. Leslie Heywood and Jennifer Drake take the third wave to be the generation born between 1963 and $1974 .{ }^{4}$ Clearly for some then, the idea of generational difference can be reduced to a matter of birth dates but for others birth dates are only relevant because the experiences that inspired individuals to become feminists in the era of Regan and Bush are radically different from those of previous generations.

This sense of there being a distinctive context for third wave feminism is noticeable in Catching a Wave, where the new social context is articulated in terms of new technologies, global capitalism, multiple models of sexuality, changing national demographies and economic decline. ${ }^{5}$ Heywood and Drake summarise this new political context as the material conditions of economic globalisation and 
technoculture. ${ }^{6}$ For similar reasons, Alfonso takes the third wave to be a distinct political generation, a group of people who share formative social conditions at approximately the same point in their lives and hold a common interpretive framework shaped by those historical circumstances. ${ }^{7}$ The political context of the third wave is thus 'conservative modernisation' - a curious blend of neo-liberal commitments to the market, neo-conservative values, new managerial or bureaucratic processes and innovative information and communication technologies. ${ }^{8}$

II

\section{Generational Conflict}

Third wave feminists do not just define themselves in terms of a shared political context that combines 'free-market' fiscal policy and social regulation but, also in relation to previous waves of the women's movement. From its early formation, this third wave was marked by the question of whether or not third wave and postfeminism were synonymous or whether third wave feminism was an extension of second wave feminism; especially with its critical interrogation of the logic of identity and identification. An extension it may have been, but it defined itself not merely as the next stage of feminism but as against the second wave. In 'Making Waves and Drawing Lines', Cathryn Bailey suggests that whereas second wavers saw themselves as carrying many of the basic values and aims of the first wave, third wavers seem to define themselves more negatively, primarily against the values and beliefs associated with the second stage. ${ }^{9}$

The idea that second wave feminists somehow policed morality and sexuality, developed 'victim' feminism and enforced binary identity runs through much third wave literature. According to Walker, the second wave refused to acknowledge individuality, complexity and less than perfect histories. In its puritanical and repressive zeal it insisted on homogeneity and deployed regulative ideals of 'perfect' identity. ${ }^{10}$ More trenchantly, it is argued, this perfect identity was actually white and middle-class. In response, third wavers see themselves shedding attachments to 'universalism, naturalism and esssentialism'. ${ }^{11}$ To avoid this conceptual triad, Dicker and Piepmeier for instance, identify the theoretical commitments of third wave

\section{Gillian Howie, Feminist Histories: Conflict, Coalitions and the Maternal Order}


'power' feminism as postmodernism and poststructuralism; theory permeated by paradox, messiness and multiplicity. ${ }^{12}$

Given that there is some continuity with the second wave project, Dicker and Piepmeier suggest that the feminist identity of young women is secured through asserting some distinctiveness about the most recent or third wave. Here is the problem. The suggestion that young feminists need a political identity and that such political identity is in conflict with and secured through the negation of a previous generation establishes psychodrama as the condition of the feminist historical narrative. The generational account, where the 'younger' generation pits itself against an 'older' generation and then (or in order to) establishe(s) itself as separate and independent, can be described as a matraphor; the use of the maternal image as a way of mapping events within a particular chronology. Given the hostility and rejection shown by some third wave feminists to second wave feminisms, Louise Bernikow describes the relationship between second and third waves as political matricide. ${ }^{13}$ The description of second wave feminism as somehow the mother of the third wave explains the relationship in terms of an unconscious psychodynamic of identification and rejection; or, in Judith Butler's terms, dis-identification.

Dis-identification is a term used by Butler to explain how it is possible to resist effectively and to undermine the existing socio-symbolic order. ${ }^{14}$ According to Muñoz, feminism is plagued by a problematic history of strict identification, creating the feminist subject as a white, straight, middle-class woman and counteridentification; hailing women in opposition to men. Thus for Muñoz, disidentification is a way not to reject but to reclaim feminism. It is a third mode of dealing with dominant ideology, one that neither opts to assimilate within the structure nor actively opposes it (such as counter-identification); it is a strategy on and against dominant ideology. Even when that dominant ideology is feminism itself. ${ }^{15}$

This 'cultural politics of dis-identifications' is undoubtedly fruitful. But it still draws on the idea of unconscious investment and resistance and risks collapsing political resistance with resistance understood in a straightforward psychoanalytic sense. It also tends to present feminism as monolithic and homogeneous. My point here is not that of Žižek. For Žižek the question is whether there is first passionate attachment or first primordial disattachment which triggers the need for fantasmatic

\section{Gillian Howie, Feminist Histories: Conflict, Coalitions and the Maternal Order}


primordial passionate attachment. ${ }^{16}$ Nor is it to question the often implicit Althusserianism with its commitment to ideology and interpellation. It is to pick up and develop Astrid Henry's point that contemporary feminism has become overdetermined by the mother-daughter trope; by the language of identification, counter-identification and resistance. ${ }^{17}$

The mother-daughter trope accentuates inter-generational conflict between feminists and presents intellectual disagreement in terms of identification with, or breaking away from, symbolic, second-wave mothers. It is a trope within which Oedipal matricide, rather than patricide, renders identity and delivers just entitlement. In effect it evacuates all meaning and makes our historical narrative an endless repetition of the same. I submit that if there is disappointment between generations, suggested by the wave metaphor, it does not indicate infantile conflict and its postpubescent resolution, but instead gestures towards structural conditions of unfulfilled promise and aspiration. Instead of the Oedipal matraphor, we need a way to make sense of this political context of third wave feminism and to open conversations across and through feminist waves. Only then will we be able to recover and refresh emancipatory critique and aspiration.

\section{III}

\section{Historical Hermeneutics and the Placental Economy}

Notwithstanding Kristeva's protestations that 'generation' suggests less a chronology than an attitude, the generational account actually maps social, intellectual and political history onto a linear line of historical progression. Rather than co-existing generations, or parallel lines, it is the notion of linear generation that we find woven through the wave metaphor. The wave metaphor suggests that one wave follows another, superseding and incorporating the previous wave, and that, despite some currents, the movement is forwards. ${ }^{18}$ This sense of a wave sublating the previous, including it and moving onwards echoes in the memory of feminists, some of whom would like to claim this time for their own as well as feminists disposed to disavow their younger selves. It presents certain strands of poststructuralism, postmodernism and psychoanalytic theory as the culmination of philosophical argument.

\section{Gillian Howie, Feminist Histories: Conflict, Coalitions and the Maternal Order}


The matraphor casts feminist theory in terms complicit with hegemonic models of conflict between women, but it also acts as a 'cover concept'. A 'cover concept' disguises tension and mystifies interests underlying conflict. The identification of third wave feminismin terms of generation or chronology (dates), political context ('post-fordism' and conservative modernisation) and theoretical commitments (poststructuralism / psychoanalysis) shows a tendency to confuse the logic of intellectual debate with the condition of the world. This means that ways of interpreting, analysing and grasping historical events become subsumed within one theoretical perspective and that those theoretical commitments are represented quite teleologically: postmodernism is mapped onto post-fordism as the next historical stage. Whatever the reason for this, there is work to be done rethinking the relationship between the theory of history and the history of feminist theory.

Peeling apart the history of theory from the theory of history can only ever be an ambition, but it remains true that in order to break apart the generational and teleological matraphor evident in the model of waves, we need to rethink feminist history. Our ability to narrate historically at all depends on what Luce Irigaray calls the syntax of communication and what Hans-Georg Gadamer describes as our ability to engage in conversation. ${ }^{19}$ Such a conversation between women, a woman-towoman sociality, requires a new covenant; one that links the past, present and future. I suggest that we can find a way to this through, paradoxically, an image of maternity. The image of maternity can release us from the generational paradigm, but only if we accept that temporal and maternal orders need not coincide. This image then is an 'unhistorical' thought and, for Nietzsche at least, confidence in the future depends on being able to sense when one ought to feel historically but also when one ought to feel unhistorically. ${ }^{20}$ Here then a utopic moment; the impossible 'unhistoric' thought that is the condition for woman-to-woman sociality, which is itself a condition for conversation and historical narrative.

In a recent interview, Irigaray perceptively notes that if stages in the feminist movement correspond to waves, we should consider this image as suggesting an affinity with water, fluidity and the sea; ceaseless and restless movement. ${ }^{21}$ Unstable and affected by things external to itself, this movement cannot assume a definitive meaning or form. Cleaving this image from historical teleology, she draws attention to

\section{Gillian Howie, Feminist Histories: Conflict, Coalitions and the Maternal Order}


the fact that the image refers us to a mythical, rather than historical, time. To consider woman-to-woman sociality we must reconsider temporality; how historical time intersects with mythical time. Two questions then follow: what is this mythical time? How can we articulate mythical time with historical time?

For Irigaray, a metaphor or an image, will always take place within the context of a phallogocentric system of representation. Yet without such images, women are 'a blank space', a refusal of representation. Irigaray considers a third way: 'by resolutely focusing on the blank spaces of masculine representation, and revealing their disruptive power'. ${ }^{22}$ A metaphor establishes a relationship and yet leaves something to imagination. If we conceive mental activity in its relation to bodily activity, then we could say that conceptual metaphors, such as that of the wave, could be motivated by underlying pre-linguistic schemas concerning space, time, and movement. This embodiment hypothesis would direct us to corporal levels of experience; to the two main boundaries of skin and physical object. The metaphorical association of waves with ebbs, flows and cross-currents as a way to understand altercations within feminist theory and the women's movement directs us back to the sea and then ultimately back to the corporeal level of experience.

Picking up the Cartesian metaphor that equates res cogitans with a pilot of a ship, Irigaray asks what is this sea that the pilot must navigate as it threatens to overwhelm him? The Cartesian 'I' will attempt to subject the sea to a whole range of techniques that will transform her, the sea, into an object of use. 'The 'I' thinks, therefore this thing, this body that is also nature, that is still the mother, becomes an extension at the 'I''s disposal for analytical investigations, scientific projections, the regulated use of the imaginary, the utilitarian practice of technique. ${ }^{, 3}$ The ' $I$ ' that navigates through waters chartered by himself is the same 'I' who attempts to manage the sea and all that is extension and who reasons to the existence of an infinite being, reproducing (for) himself a (mother)-father in his own image. In these thoroughly Cartesian images, we can detect the omission and exclusion of actual sex from the masculine imaginary.

If claims to know what is the case are actually subtended by an unacknowledged mother and our historical narrative depends on such claims then we need to find a place for maternal genealogy within the symbolic. If the 'I' that thinks 'woman' only

\section{Gillian Howie, Feminist Histories: Conflict, Coalitions and the Maternal Order}


does so because she, the mother, has already been incorporated into the masculine imaginary, then let's take the sexing of the 'I' subject/she seriously. Not the single, neutral/neutered subject which generates the world - copula without copulation - not a subject who derives power from appropriating the non-place of the mirror. Instead, let us conceive a subject already two or more, maybe a partial subject recognising the partial other as sexed, even when that sex is not yet known. This would be a subject already in tune with the otherness of the specific other, oriented towards qualitative difference.

As a critical intervention into Lacanian psychoanalytic theory we could say that symbolic castration is naturalised by projecting lack, or chaos, onto the female body and that this enables men to avoid facing their own castration or separation anxiety. This deflection is then disguised through numerous naturalised representations of women. ${ }^{24}$ Unless then women find a way to represent their relation to their mother as well as to maternity and thus to origins outside this masculine paradigm then we will always find ourselves devalued. More significantly, without a way to imagine, conceive or represent this relationship women will tend towards rivalry; a rivalry at the very least encouraged by the competitive aggression of the market. ${ }^{25}$ Let us consider the Maternal Order as a way to re-imagine this relationship. In discussion with Hélène Rouch, Irigaray draws attention to the mediating role of placenta. Placental mechanisms designed to block maternal immune reactions are only put in operation if there has been recognition by the maternal organism of foreign antigens. Placenta is not an automatic protection system. Clarifying this, Rouch draws a distinction between placenta and organ transplant, and points out that the embryo is half-foreign to the maternal organism and as such the mother's body 'should' activate her defence mechanisms to reject this other self. But the placenta, which is also an other, prevents this mechanism from being activated, but only locally and in a way that allows the mother to maintain her defensive capabilities against potential infection. ${ }^{26}$

This negotiation brings into question the patriarchal presentation of the childmother relationship as one of fusion that depends on the interjection of Law for separation. What appears within the Cartesian phantasy to be boundless, needing to be charted, traversed and controlled, actually already contains a different sensibility and

\section{Gillian Howie, Feminist Histories: Conflict, Coalitions and the Maternal Order}


a sensibility of difference. What if she, the mother, was there in the beginning? Already two, or more? The singularity of the relations between mother and child/children in utero suggests a distinctive imaginary, one that is qualitatively different.

The Maternal Order suggests a way to think the antecedence of an ethical relationship. In I love to You, Irigaray notes that to recognise an identity within oneself is to recognise the negative within oneself: 'I am sexed' implies I am not everything. It is not a way to reflect myself back to me. The negative can thus maintain a duality of subjectivities. The negative within the self creates a space for meeting and attending. Similarly, 'I am called to you' - a you that is and yet is not present to me - is a call which prepares the way for the not-coded, for space, for silence, space for existence and support for becoming. ${ }^{27}$ If it is the case that to speak from the already seen and known introduces a stasis, a hiatus of becoming, then an other who is not visually present, cannot be known or claimed so easily. Called by the other yet unable to determine the other, we have the beginnings of an ethical relationship. Where is this more simple pure than in the in utero relationship?

This original mythical time then is posed through the I/eye of the mother rather than through symbols of anxious and masculine infancy, where love is recycled as a loss of plenitude and which demands, in reparation, loving self-renunciation, by wife or mother. It is this underlying psychodrama which is repeated in the matraphorical generational narrative of feminist history. Side-stepping the truth claims of psychoanalysis, the thought of a different mythical origin provokes a different historical narrative and offers a way to hear the past in light of the new without anxious displacement.

All such myths are perilous. Any association of the feminine with maternity or generation may strike some as free play within the masculine symbolic. We risk assimilating all forms of difference to an idealised version of the feminine. Of course, it is true that any mother gambles with her own identity, just as she can have a sense of possession or entitlement that claims ownership. That said, surely in order to escape spaces, roles and gestures assigned to us and to overcome a de facto rivalry, where and if it exists, it is important for women to join together 'amongst ourselves'. Another style of collective organisation, free from sororal anxiety permeating the

\section{Gillian Howie, Feminist Histories: Conflict, Coalitions and the Maternal Order}


generational account of the women's movement requires another style of collectivity and another relationship to space and time. And this is exactly why historical and mythic time need to be seen as intersecting but not isomorphic.

Let us return to the suggestion that the wave metaphor articulates a mythical time. The term 'myth' identifies a sacred narrative often linked to spiritual or religious life of a community and 'mythic time' to the universal and local beginnings of the community. The mythic, but not phantastical, maternal order introduces a new sensibility into the generational account. The generational account of the women's movement is, as we have seen, often characterised in terms of conflict, resistance, and denial. I suggest that the thought of the Maternal Order, so well expressed in je, $t u$, nous, offers a new hermeneutic of difference and a more developed sensibility; an image of the recognition by the mother of the other and her sensed responsibility towards the other; where the self and the other are continually renegotiated. It is the vulnerability of the other that commands. From this we can build a 'we': a being-with. This mythic moment of the maternal order not only helps to reorientate cognition but also unlocks ways to approach embodied - relational and unique - differences. For us, it also demonstrates the possibilities of being-with and being in it together.

IV

\section{Conclusion}

Let us return to the description of our historical time, so well expressed in Catching a Wave. We live, according to Dicker and Piepmeier, in a time of global capitalism, economic decline and changing national demographies. The world they describe is remarkably familiar; it is a world of gender inequity. But it seems to me that, despite positing continuity with the second wave, they are largely without the analytic tools required to make sense of the conditions they acutely describe and with which they creatively engage. This theoretical lacuna is, in part, a consequence of the generational historical narrative, whereby a rich stream of critical social science is forgotten rather than repressed; the result of the overwhelming dominance of cultural theory, poststructuralism, psychoanalysis and - perhaps - the municipalisation of feminist theory. ${ }^{28}$ 
But whatever the reason, there is work to be done unpicking the relationship between the history of feminist theory and philosophies of history and time that are emerging from within feminism. A starting point may be a synchronic and diachronic account of the history of feminist theory. This should be able to deliver three things. Firstly, it would be able to take into account particular (social, political, philosophical) contexts within which theory is formulated and received. Secondly, it would incorporate this into an understanding of differing ways in which the reception of the theory might reformulate and interpret the key problems within that which is received. Lastly, there might be enough space to consider the trans-historical and inter-contextual conversation that occurs around problems and questions; in our case the problem of subjection.

The metaphor of waves as a way to conceptualise stages in the woman's movement takes us back to the sea thence to the Maternal Order and this can introduce an ethical sensibility with which to understand the generational and historical direction of feminist theory and the woman's movement. From within the mythic time of the maternal order, which is - it has to be stressed - not bound by linear temporality, is generated a discursive and ethical orientation that helps us articulate the historic ebbs and flows of the women's movement. The recognition of otherness, of alterity, whilst not the supreme goal of feminism, may well be the condition of historical narrative and woman-to-woman sociality, which is itself the condition for political intervention. It means being able to attend to the call others and enter into conversation without the psychoanalytic psychodrama of anxious displacement, sororal conflict and repression. From within the theory of sexuate difference and the Maternal Order emerge pathways through feminisms and between feminists. 'I can agree to recognise a reality that is foreign to me, that will never be mine but which determines me and with which I am in relation... Such a change in the nature of the constitution of subjectivity and the recognition of the other as another, irreducible to me and unthinkable in terms of my spirit, could be the opening up of a period of history yet to come'. ${ }^{29}$

\section{Gillian Howie, Feminist Histories: Conflict, Coalitions and the Maternal Order}


${ }^{1}$ Julia Kristeva, 'Women's Time' in Feminist Theory: A Critique of Ideology, ed. by N. Keohane, M. Rosaldo and B. Gelpi (Sussex: Harvester, 1982), pp. 31-53

${ }^{2}$ Astrid Henry takes issue with this, arguing that the term emerged five years earlier in 'Second Thoughts on the Second Wave', written by Deborah Rosenfelt and Judith Stacey. Astrid Henry, 'Daughterhood is Powerful' in The Women's Movement Today: An Encyclopedia of Third Wave Feminism edited by Leslie Heywood (Westport: Greenwood, 2006): 121

${ }^{3}$ Leslie Heywood and Jennifer Drake, Third Wave Agenda: Being Feminist, Doing Feminism (Minneapolois: Minnesota UP, 1997); Jennifer Baumgardner and Amy Richards, Manifesta: Young Women, Fmeinism and the Future (New York: Farrar, Straus and Giroux, 2000); Rory Dicker and Alison Piepmeier (eds), Catching a Wave: Reclaiming Feminism for the $21^{s t}$ Century (Boston: Northeastern UP, 2003).

${ }^{4}$ Quoted in Stacy Gillis, Gillian Howie and Rebecca Munford (eds), 'Introduction' in Third Wave Feminism: A Critical Exploration (Basingstoke: Palgrave, 207) pp. xxii. See also S. Gillis and R. Munford, 'Genealogies and Generations: The Politics and Praxis of Third Wave Feminism', Women's History Review 13:2 (2004), 165-78.

${ }^{5}$ Rory Dicker and Alison Piepmeier (eds), Catching a Wave: Reclaiming Feminism for the $21^{\text {st }}$ Century (Boston: Northeastern UP, 2003). 10

${ }^{6}$ Leslie Heywood and Jennifer Drake, “'It's All About the Benjamins”: Economic Determinants of the Third Feminism in the United States' in Third Wave Feminism: A Critical Exploration edited by Stacy Gillis, Gillian Howie and Rebecca Munford (Basingstoke: Palgrave, 207) pp. 114.

${ }^{7}$ For instance R. Alfona and J. Trigilio, 'Surfing the Third Wave', Hypatia 12:3 (1997), 3.

${ }^{8}$ M. Apple, 'Education, Markets and an Audit Culture,' Critical Quarterly 47:1-2 (2005), 11-29.

${ }^{9}$ C. Bailey, 'Making Waves and Drawing Lines: The Politics of Defining the Vicissitudes of Feminism', Hypatia 12:3 (Summer 1997).

${ }^{10}$ Rebecca Walker, 'Being Real: An Introduction' in The Women's Movement Today: An Encyclopedia of Third Wave Feminism, ed. by Leslie Heywood (Westport: Greenwood, 2006).

${ }^{11}$ Elizabeth Grosz, 'Sexual Difference and the Problem of Essentialism,' in The Essential Difference, ed Naomi Schor and Elizabeth Weed (Bloomington and Indianapolis: Indiana University Press, 1994), 85.

${ }^{12}$ Rory Dicker and Alison Piepmeier eds, Catching a Wave: Reclaiming Feminism for the $21^{\text {st }}$ Century (Boston: Northeastern University Press, 2003).

${ }^{13}$ Louise Bernikow quoted Madeline Detloff, 'Mean Spirits: The Politics of Contempt Between Feminist Generations’, Hypatia 12:3 (Summer 1997), 76-99.

${ }^{14}$ Judith Butler, Bodies that Matter: on the Discursive Limits of 'Sex' (New York and London: Routledge, 1993), 4.

15 Jose Muñoz, Disidentification: Queers of Colour and the Performance of Politics (Minneapolis: University of Minnesota Press, 1999). Also D. M. Mestiza, 'O Gender: Notes Towards a Transformative Masculinity'. http://www.beyondmasculinity.com/articles/martinez.php. Discussed in

Feminist Histories: Conflict, Coalitions and the Maternal Order

Studies in the Maternal, 2 (1) 2010, www.mamsie.bbk.ac.uk 
Jonathan Dean, “'The Lady Doth Protest Too Much?': Theorizing Disidentification in Contemporary Gender Politics,” Working Paper in Discourse Analysis, 24 (2008).

${ }^{16}$ Žižek argues that it might make more sense to question whether there is first passionate attachment or first primordial disattachment latterly expressed in a need for fantasmatic passionate attachment. Slavoj Žižek, From 'Passionate Attachments to Dis-Identification'. Umbr(a) (1988) http://www.lacan.com/zizekpassionate.htm

${ }^{17}$ Astrid Henry, 'Daughterhood is Powerful' in The Women's Movement Today: An Encyclopedia of Third Wave Feminism ed. by Leslie Heywood (Westport: Greenwood, 2006), pp. 125.

18 Gillian Howie, 'Breaking Waves: Feminism and Marxism Revisited' in Karl Marx and Contemporary Philosophy, ed. by Andrew Chitty and Martin McIvor (Basingstoke: Palgrave, 2009).

${ }^{19}$ Hans-Georg Gadamer, Truth and Method (London: Sheed and Ward, 1979), 347

${ }^{20}$ Fredrich Nietzsche, 'On the Uses and Disadvantages of History' in Untimely Meditations trans R. Hollingdale (Cambridge: Cambridge University Press, 1983), pp. 76

${ }^{21}$ Gillian Howie 'Interview With Luce Irigaray' in Third Wave Feminism op cit.: 319.

${ }^{22}$ Elizabeth Berg, quoted in Margaret Whitford, Luce Irigaray: Philosophy in the Feminine (New York and London: Routledge, 1991), pp. 71

${ }^{23}$ Speculum of the Other Woman, trans Gillian C. Gill (Ithica: Cornell University Press, 1985), pp. 1867.

${ }^{24}$ Margaret Whitford, Luce Irigaray: Philosophy in the Feminine (New York and London: Routledge, 1991), 84

${ }^{25}$ It is my suspicion that the relationship between the munipalisation of feminism, the entry of feminist theory into higher education, and the wave metaphor, presenting feminist theory in terms of conflict and transcendence, is not accidental.

${ }^{26}$ je, tu, nous: Towards a Culture of Difference, trans Alison Martin (New York: Routledge, 1993), pp. 38-41).

${ }^{27}$ I Love to You: Sketch for a Felicity Within History, trans Alison Martin (New York: Routledge, 1996), pp. 116.

${ }^{28}$ Gillian Howie and Ashley Tauchert, 'Institutional discrimination and the 'Cloistered' Academic Ideal' in Gender, Teaching and Research in Higher Education: Challenges for the $21^{\text {st }}$ Century, ed. by Gillian Howie and Ashley Tauchert (Aldershot: Ashgate, 2002), pp. 59-72.

${ }^{29}$ I Love to You: Sketch for a Felicity Within History, trans Alison Martin (New York: Routledge, 1996)pp. 56-7.

Feminist Histories: Conflict, Coalitions and the Maternal Order

Studies in the Maternal, 2 (1) 2010, www.mamsie.bbk.ac.uk 